\title{
Comparison of the chemical composition and anti-methanogenic potential of Liquidambar orientalis leaves with Laurus nobilis and Eucalyptus globulus leaves using an in vitro gas production technique
}

\author{
Ismail Ulger', Adem Kamalak², Ozer Kurt², Emrah Kaya², Inan Guven² \\ ${ }^{1}$ Erciyes University, Seyrani Faculty of Agriculture, Department of Animal Science. Kayseri, Turkey \\ ${ }^{2}$ Kahramanmaras Sutcu Imam University, Faculty of Agriculture, Department of Animal Science. \\ Kahramanmaras, Turkey
}

\begin{abstract}
I. Ulger, A. Kamalak, O. Kurt, E. Kaya, I. Guven. 2017. Comparison of chemical composition and anti-methanogenic potential of Liquidambar orientalis leaves with Laurus nobilis and Eucalyptus globulus leaves using in vitro gas production technique. Cien. Inv. Agr. 44(1): 75-82. The aim of the present study was to compare the leaves of Liquidambar orientalis with the leaves of Laurus nobilis and Eucalyptus globulus in terms of their chemical composition and anti-methanogenic potential using an in vitro gas production technique. Species had a significant effect on the chemical composition, gas production, methane production, metabolizable energy and organic matter digestibility of the tree leaves. The crude protein $(\mathrm{CP})$, neutral detergent fiber (NDF), acid detergent fiber (ADF) and condensed tannin (CT) contents of the tree leaves ranged from 9.11 to $12.8,22.49$ to $35.85,32.76$ to 49.31 , and 1.55 to $9.29 \%$, respectively. The gas production, methane production, metabolizable energy (ME) and organic matter digestibility (OMD) ranged from 21.72 to $31.54 \mathrm{~mL}, 2.62$ to $4.41 \mathrm{~mL}$, 6.62 to $9.24 \mathrm{MJ} \mathrm{kg}^{-1}$ dry matter (DM), and 41.23 to $54.84 \%$, respectively. It is likely that the leaves of $L$. orientalis would be more effective for methane mitigation in ruminant animals than those of E. globules or L. nobilis. However, prior to widespread implementation, the effect of the leaves of $L$. orientalis on animal production should be tested in vivo.
\end{abstract}

Key words: Anti-methanogenic potential, chemical composition, digestibility, L. orientalis leaves, metabolizable energy.

\section{Introduction}

It is well known that tree leaves have long been used to meet the protein, energy and mineral requirements of ruminant animals in most parts of the world during feedstuff shortages. It has

Received September 07, 2016. Accepted March 10, 2017 Corresponding author: akamalak@ksu.edu.tr been reported that during ruminal fermentation, $2-12 \%$ of dietary energy intake is lost as methane, which contributes considerably to global warming (Jonhson and Johnson, 1995). Recently, tree leaves and their secondary metabolites, such as tannins, saponins and essential oils, have attracted considerable attention among researchers and have been tested for anti-methanogenic potential to mitigate the enteric methane emissions from 
ruminant animals (Kilic et al., 2011; Akcil and Denek, 2013; Thao et al., 2014; Kumar et al., 2012; Kouazounde et al., 2015). Several researchers have tested the leaves of Laurus nobilis and Eucalyptus globulus trees and their secondary metabolites for their anti-methanogenic potential. It has been reported that L. nobilis and E. globulus trees and their secondary metabolites have potential to mitigate enteric methane emissions (Kilic et al., 2011; Akcil and Denek, 2013; Kouazounde et al., 2014; Thao et al., 2014, 2015). L. orientalis, which can grow to $10-15 \mathrm{~m}$, is a native tree species in Turkey whose leaves contain essential oils similar to those in the leaves of L. nobilis and E. globules. Although the essential oil from $L$. orientalis has been reported to have anti-microbial activity (Okmen et al., 2014; Yapici et al., 2015), thus far, the anti-methanogenic potential of $L$. orientalis leaves has not been tested. The in vitro gas production method is used for various purposes, such as for the determination of the fermentation kinetics of feedstuffs and the evaluation of the effects of anti-nutritive factors and of the associative effects of feedstuffs (Ozturk et al., 2006; Aydin et al., 2007; Goel et al., 2008; Kamalak et al., 2011; Akcil and Denek, 2013). Recently, this method has been used to determine the anti-methanogenic potential of essential oils; various solvent extracts; and tree leaves containing essential oils, tannins and saponins (Kim et al., 2012; Akcil and Denek, 2013; Yogianto et al., 2014). Therefore, the aim of the present study was to compare the leaves of $L$. orientalis with the leaves of L. nobilis and E. globulus in terms of the chemical composition and anti-methanogenic potential using an in vitro gas production technique.

\section{Materials and methods}

Leaf samples of L. orientalis, L. nobilis and E. globulus were collected from seven different trees in June 2015 in Kahramanmaras, Turkey, and dried under shade at room temperature. Dry leaf samples were milled for passing through a 1-mm screen and kept in airtight plastic bags for subsequent chemical analysis and in vitro gas production.

Dry matter, crude ash, crude protein and ether extract contents of tree leaves were determined according to the AOAC (1990). Cell wall (NDF and ADF) contents of tree leaves were determined according to the methods described by Van Soest and Wine (1967) and Georing and Van Soest (1963), respectively. Condensed tannin contents were determined using the methods of Makkar et al. (1995). The chemical analysis was carried out in triplicate.

Leaf samples $(0.200 \mathrm{~g})$ were incubated with buffered rumen liquid in triplicate to determine the gas and methane production after $24 \mathrm{~h}$ of incubation using the in vitro gas production technique (Menke et al., 1979). Net gas productions of tree leaves was obtained after correction for blank and hay standards (University of Hohenheim, Germany) with a predicted gas production of $49.61 \mathrm{~mL}$ per $0.200 \mathrm{~g}$.

The rumen fluid was collected prior to morning feeding from two fistulated Awassi sheep fed a diet consisting of alfalfa hay ( $800 \mathrm{~g}$ ) and barley (400 g) and was then filtered through four layers of cheesecloth under flushing with $\mathrm{CO}_{2}$. The buffered rumen liquid was then obtained by combining buffered solution with rumen liquid at the ratio of $1: 2$, respectively.

$\mathrm{ME}(\mathrm{MJ} / \mathrm{kg} \mathrm{DM})$ and OMD of tree leaves were estimated using the equation of Menke and Steingass (1988) as follows:

$\mathrm{ME}(\mathrm{MJ} / \mathrm{kg} \mathrm{DM})=1.68+0.1418 \mathrm{GP}+0.073 \mathrm{CP}$ $+0.217 \mathrm{EE}-0.028 \mathrm{CA}$

OMD $(\%)=14.88+0.8893 \mathrm{GP}+0.448 \mathrm{CP}+$ $0.651 \mathrm{CA}$

where $\mathrm{GP}=24 \mathrm{~h}$ of net gas production $(\mathrm{mL} 200$ $\left.\mathrm{mg}^{-1}\right) ; \mathrm{CP}=$ crude protein $(\%) ; \mathrm{EE}=$ ether extract $(\%)$; and $\mathrm{CA}=$ ash content $(\%)$ 
The methane content of gas produced after $24 \mathrm{~h}$ of incubation was determined using an infrared methane analyzer (Sensor Europe GmbH, Erkrath, Germany) (Goel et al., 2008) based on the following equation:

Methane production $(\mathrm{mL})=$ Total gas production $(\mathrm{mL}) \mathrm{X}$ Percentage of methane $(\%)$

The data obtained in the current experiment were first subjected to Levene's test to determine the variance of homogeneity. The effects of the species on the chemical composition, gas production, methane production, ME and OMD of tree leaves were determined using one-way analysis of variance (ANOVA). Tukey's multiple range test was employed to identify the significance between means. Mean differences were considered significant at $\mathrm{P}<0.05$.

\section{Results and discussion}

The effect of species on the chemical composition of tree leaves is given in Table 1. Species had a significant effect on the chemical composition.

The crude ash content of the tree leaves ranged from 4.42 to $9.44 \%$. The crude ash content of $L$. orientalis was significantly higher than that of L. nobilis but lower than that of E. globulus. The crude protein content of the tree leaves ranged from 9.11 to $12.85 \%$. The crude protein of $L$. orientalis was similar to that of $L$. nobilis but lower than that of E. globulus. All tree leaves involved in this experiment contained enough $\mathrm{CP}$ to meet the minimum crude protein requirement $(8 \%$ of DM) for optimal microbial function. However, high levels of condensed tannins in L. nobilis and L. orientalis may hinder the protein utilization. Kumar and Singh (1984) suggested that protein digestibility can decrease due to high levels of condensed tannins, which combine with proteins, resulting in a less-digestible complex.

The neutral detergent fiber content of the tree leaves ranged from 32.76 to $49.31 \%$. The NDF content of $L$. orientalis was significantly higher than that of E. globulus but lower than that of L. nobilis. On the other hand, the ADF content of the tree leaves ranged from 22.49 to $35.85 \%$. The acid detergent fiber content of $L$. orientalis was similar to that of E. globulus but lower than that of L. nobilis.

The ether extract content of the tree leaves ranged from 4.33 to $11.15 \%$. The ether extract content of L. orientalis was significantly lower than that of L. nobilis and E. globulus. It is well known that the energy value of fat is higher than that of carbohydrates and protein in feedstuffs. Therefore, the contribution of fat to the energy value of $L$.

Table 1. The effect of species on the chemical composition of tree leaves.

\begin{tabular}{lccccc}
\hline \multirow{2}{*}{ Parameters } & \multicolumn{3}{c}{ Tree species } & \multirow{2}{*}{ SEM } & Sig \\
\cline { 2 - 3 } & L. nobilis & L. orientalis & E. globulus & & $* * *$ \\
DM & $39.37 \mathrm{a}$ & $36.61 \mathrm{~b}$ & $39.77 \mathrm{a}$ & 0.426 & $* * *$ \\
$\mathrm{CP}$ & $4.42 \mathrm{c}$ & $6.82 \mathrm{~b}$ & $9.44 \mathrm{a}$ & 0.133 & $* * *$ \\
NDF & $9.26 \mathrm{~b}$ & $9.11 \mathrm{~b}$ & $12.85 \mathrm{a}$ & 0.184 & $* * *$ \\
ADF & $49.31 \mathrm{a}$ & $38.57 \mathrm{~b}$ & $32.76 \mathrm{c}$ & 1.046 & $* * *$ \\
EE & $35.85 \mathrm{a}$ & $22.49 \mathrm{~b}$ & $23.37 \mathrm{~b}$ & 1.399 & $* * *$ \\
CT & $9.44 \mathrm{~b}$ & $4.33 \mathrm{c}$ & $11.15 \mathrm{a}$ & 0.439 & $* * *$ \\
\hline
\end{tabular}

a b c Row means with common superscripts do not differ $(\mathrm{P}<0.05)$; SEM - standard error mean; Sig - significance level; DM - Dry matter (\% of fresh), CA: crude ash (\% of DM), CP - Crude protein (\% of DM), NDF - Neutral detergent fiber ( $\%$ of DM), ADF - Acid detergent fiber ( $\%$ of DM), EE: Ether extract (\% of DM), CT - Condensed $\operatorname{tannin}(\%$ of DM), $* * * \mathrm{P}<0.001$. 
nobilis and E. globulus would be higher due to the high EE content compared with that of $L$. orientalis leaves.

The condensed tannin content of the tree leaves ranged from 1.55 to $9.29 \%$. The condensed tannin content of $L$. orientalis was similar to that of $L$. nobilis but higher than that of E. globules. Schofield et al. (2001) indicated that the effect of CTs on the digestibility of nutrients and performance in an animal depends on the amount and biological activity of the condensed tannins. Although low levels of CTs have positive effects on the digestibility of nutrients and performance in animals, high levels of CTs ( $5 \%$ of DM) lead to decreases in protein utilization due to excessive formation of tannin-protein complexes (Kumar and Singh, 1984). Therefore, care must be taken when the leaves of $L$. orientalis and L. nobilis are incorporated into ruminant diets since the CT contents of $L$. orientalis and L. nobilis leaves were higher than that considered detrimental to ruminant animals. On the other hand, in the current experiment, the condensed tannin concentration of E. globules leaves was lower than that considered detrimental to ruminant animals.

The effect of species on the gas production, methane production, metabolizable energy and organic matter digestibility of the tree leaves is given in Table 2. Species had a significant effect on gas production, methane production, metabolizable energy and the organic matter digestibility of tree leaves. Gas production of $L$. orientalis was significantly higher than that of $L$. nobilis but lower than that of E. globulus. Methane production (mL or $\%$ ) of L. orientalis was significantly lower than that of L. nobilis and E. globulus. Metabolizable energy of $L$. orientalis was significantly lower than that of L. nobilis and E. globulus. On the other hand, the organic matter digestibility of $L$. orientalis was significantly lower than that of $E$. globulus but higher than that of L. nobilis.

In terms of the methane reduction potential, feedstuffs can be classified into three groups, namely, low potential ( $\%$ methane in gas between 11 and $14 \%)$, moderate potential (\% methane in gas between 6 and 11\%), and high potential (\% methane in gas between 0 and $6 \%$ ), based on the percentage of the methane content in the gas produced in vitro after $24 \mathrm{~h}$ (Lopez et al. 2010). As seen from Table 2, L. nobilis and E. globules leaves have low potential for methane reduction, whereas $L$. orientalis leaves have a moderate potential for methane reduction.

Correlation coefficients (r) of the relationships of chemical composition with in vitro methane production and estimated parameters are given in Table 3.

Gas production was positively correlated with $\mathrm{CA}$ and $\mathrm{CP}$, whereas gas production was negatively correlated with the cell wall contents (NDF and $\mathrm{ADF}$ ) and CT contents of the tree leaves.

Table 2. The effect of species on the gas production, methane production, metabolizable energy and organic matter digestibility of tree leaves.

\begin{tabular}{|c|c|c|c|c|c|}
\hline \multirow{2}{*}{ Parameters } & \multicolumn{3}{|c|}{ Tree species } & \multirow{2}{*}{ S.E.M } & \multirow{2}{*}{ Sig } \\
\hline & L. nobilis & L. orientalis & E. globulus & & \\
\hline GP (ml) & $21.72 \mathrm{c}$ & $24.87 b$ & $31.54 \mathrm{a}$ & 0.412 & $* * *$ \\
\hline $\mathrm{CH}_{4}(\mathrm{ml})$ & $3.11 \mathrm{~b}$ & $2.62 \mathrm{c}$ & $4.41 \mathrm{a}$ & 0.098 & $* * *$ \\
\hline $\mathrm{CH}_{4}(\%)$ & $14.32 \mathrm{a}$ & $10.56 \mathrm{~b}$ & $13.98 \mathrm{a}$ & 0.322 & $* * *$ \\
\hline ME & $7.35 b$ & $6.62 \mathrm{c}$ & $9.24 \mathrm{a}$ & 0.113 & $* * *$ \\
\hline OMD & $41.23 \mathrm{c}$ & $45.52 \mathrm{~b}$ & $54.84 \mathrm{a}$ & 0.385 & $* * *$ \\
\hline
\end{tabular}

a b c Row means with common superscripts do not differ $(\mathrm{P}<0.05)$; S.E.M. - standard error mean; Sig. significance level; GP: Gas production ( $\mathrm{ml}), \mathrm{CH}_{4}-$ Methane emission ( $\mathrm{ml}$ or \%), ME: Metabolizable energy (MJ $\left.\mathrm{kg}^{-1} \mathrm{DM}\right)$, OMD: Organic matter digestibility (\%), ${ }^{* * *} \mathrm{P}<0.001$. 
Table 3. Correlation coefficient ( $\mathrm{r}$ ) of the relationship of chemical composition with in vitro methane production and estimated parameters.

\begin{tabular}{lccccccc}
\hline Parameters & $\mathrm{DM}$ & $\mathrm{CA}$ & $\mathrm{CP}$ & $\mathrm{NDF}$ & $\mathrm{ADF}$ & $\mathrm{EE}$ & $\mathrm{CT}$ \\
\hline $\mathrm{GP}$ & $0.319 \mathrm{NS}$ & $0.975^{* * *}$ & $0.928^{* * *}$ & $-0.909^{* * *}$ & $-0.690^{*}$ & $0.431 \mathrm{NS}$ & $-0.853^{* * *}$ \\
$\mathrm{CH}_{4}(\mathrm{ml})$ & $0.763 * *$ & $0.717^{* *}$ & $0.969^{* * *}$ & $-0.552 \mathrm{NS}$ & $-0.174 \mathrm{NS}$ & $0.847 * * *$ & $-0.974 * * *$ \\
$\mathrm{CH}_{4}(\%)$ & $0.916^{* * *}$ & $-0.054 \mathrm{NS}$ & $0.458 \mathrm{NS}$ & $0.252 \mathrm{NS}$ & $0.624 \mathrm{NS}$ & $0.918^{* * *}$ & $-0572 \mathrm{NS}$ \\
$\mathrm{ME}$ & $0.753^{* *}$ & $0.713^{* *}$ & $0.964 * * *$ & $-0.552 \mathrm{NS}$ & $-0.185 \mathrm{NS}$ & $0.864 * * *$ & $-0988^{* * *}$ \\
$\mathrm{OMD}$ & $0.319 \mathrm{NS}$ & $0.979 * * *$ & $0.935^{* * *}$ & $-0.909 * * *$ & $-0.685^{*}$ & $0.438 \mathrm{NS}$ & $-0.855^{* * *}$ \\
\hline
\end{tabular}

DM - Dry matter (\% of fresh), CA: crude ash (\% of DM), CP - Crude protein (\% of DM), NDF - Neutral detergent fiber (\% of DM), ADF - Acid detergent fiber (\% of DM), EE: Ether extract (\% of DM), CT - Condensed tannin (\% of DM), GP: Gas production $(\mathrm{ml}), \mathrm{CH}_{4}-$ Methane emission ( $\mathrm{ml}$ or \%), ME: Metabolizable energy ( $\mathrm{MJ} \mathrm{kg}^{-1} \mathrm{DM}$ ), OMD: Organic matter digestibility (\%), NS: Not significant, $* * * \mathrm{P}<0.001, * * \mathrm{P}<0.01, * \mathrm{P}<0.05$

This result is consistent with that of Gemeda et al. (2015). Metabolizable energy content was positively correlated with $\mathrm{DM}, \mathrm{CA}, \mathrm{CP}$ and $\mathrm{EE}$ but negatively correlated with the CT contents of the tree leaves. This result is consistent with Gemeda et al. (2015). Organic matter digestibility was positively correlated with CA and CP but negatively correlated with the cell wall contents and CT contents of the tree leaves. This result is also consistent with that of Gemeda et al. (2015). As shown in Tables 1 and 2, the gas production, $\mathrm{OMD}$ and $\mathrm{ME}$ of E. globules leaves were significantly higher than those of $L$. nobilis and $L$. orientalis leaves since the NDF and CT contents of $E$. globules leaves were lower than those of $L$. nobilis and $L$. orientalis leaves.

The cell wall contents and condensed tannin contents are very important factors affecting the nutritive value of feedstuffs. These factors are negatively correlated with nutritive value parameters of feedstuffs such as digestibility and metabolizable energy. It is well documented that cell wall contents (NDF and ADF) and condensed tannin content vary with the phenological stage of plants and increase at the expense of fermentable fractions with increasing maturity. As a result, gas production, organic matter digestibility and metabolizable energy values decrease with increasing maturity (Kamalak et al., 2011).

Purcell et al. (2011) showed that methane production per gram of incubated DM decreased with increasing maturity due to the increase of less-digestible NDF content of plants but also showed that methane production per gram of DM digested increased with increasing maturity, since fermentation of fibrous carbohydrates results in higher methane production than non-fibrous carbohydrates (Johnson and Johnson, 1995). It is likely that feedstuffs with high gas production and digestibility have high methane production per gram of DM incubated (Durmic et al., 2010; Njidda and Nasiru, 2010; Jayanegara et al., 2011). As shown in Table 2, E. globules had a higher gas production and organic matter digestibility than L. nobilis and L. orientalis. Therefore, it was expected that higher methane production $(\mathrm{mL})$ per $0.200 \mathrm{~g}$ of incubated DM from E. globules was obtained compared with that of $L$. nobilis and L. orientalis.

Methane production $(\mathrm{mL})$ was positively correlated with DM, CA, CP and EE, whereas methane production $(\mathrm{mL})$ was negatively correlated with the CT content of the tree leaves.

Methane production (\%) was positively correlated with the DM and EE contents of the tree leaves. Recently, some researchers have shown that supplementation of tree leaves containing tannins mitigates enteric methane emissions either directly by inhibition of methanogenesis or indirectly through inhibition of protozoa (Animut et al., 2008; Hristov et al., 2013). The current experiment also showed that the in vitro gas production technique is a very effective method 
for determining the anti-methanogenic potential of tree leaves.

The main conclusions are as described as follows. It is likely that leaves of $L$. orientalis will be more effective for methane mitigation in ruminant animals than E. globules and L. nobilis leaves. However, the effects of the leaves of $L$. orientalis on animal production should be tested in vivo to prior to large-scale implementation.

\section{Resumen}

I. Ulger, A. Kamalak, O. Kurt, E. Kaya, I. Guven. 2017. Comparación de la composición química y el potencial anti-metanogénico de las hojas de Liquidambar orientalis con hojas de Laurus nobilis y Eucalyptus globulus utilizando la técnica de producción de gas in vitro. Cien. Inv. Agr. 44(1): 75-82. El objetivo del presente estudio fue comparar las hojas de Liquidambar orientalis con las hojas de Laurus nobilis y Eucalyptus globulus en cuanto a su composición química y potencial anti-metanogénico utilizando una técnica de producción de gas in vitro. Las especies tuvieron un efecto significativo sobre la composición química, la producción de gas, la producción de metano, la energía metabolizable y la digestibilidad de la materia orgánica de las hojas de los árboles. El contenido de proteína en bruto (PB), fibra en detergente neutro (FDN), fibra en detergente ácido (FDA) y contenido en tanino condensado (TC) de las hojas de los árboles osciló entre 9,11 a 12,8; 22,49 a 35,85; 32,76 a 49,31 y 1,55 a 9,29\%, respectivamente. La producción de gas, la producción de metano, la energía metabolizable (EM) y la digestibilidad de materia orgánica (DMO) oscilaron entre 21,72 a 31,54 mL; 2,62 a 4,41 mL; 6,62 a 9,24 $\mathrm{MJ} \mathrm{kg}^{-1}$ de materia seca y 41,23 a 54,84\% respectivamente. Es probable que las hojas de $L$. orientalis sean más efectivas para la mitigación del metano en animales rumiantes que las de E. globules o L. nobilis. Sin embargo, antes de la aplicación generalizada, el efecto de las hojas de L. orientalis en la producción animal debe ser probado in vivo.

Palabras clave: Composición química, digestibilidad, energía metabolizable, hojas de $L$. orientalis, potencial anti-metanogénico.

\section{References}

Akcil E., and N. Denek. 2013. Investigation of different levels Eucalyptus (Eucalyptus camaldulensis) leaves effect on in vitro methane production of some roughages. Harran University Journal of Veterinary Faculty 2(2):75-81.

Animut, G., R. Puchala, A.L. Goetsch, A.K. Patra, T. Sahlu, V.H. Varel, and J. Wells. 2008. Methane emission by goats consuming different sources of condensed tannins. Anim. Feed Sci. Technol. 144:228-241.

AOAC. 1990. Official method of analysis. 15th ed., pp.66-88. Association of official analytical chemists, Washington, DC, USA.
Aydin, R., A. Kamalak, and O. Canbolat. 2007. Effect of maturity on the potential nutritive value of burr medic (Medicago polymorha) hay. Journal of Biological Science 7(2):300-3004.

Durmic Z., P. Hutton, D.K. Revell, J. Emms, S. Hughes, and P.E. Vercoe. 2010. In vitro fermentability traits of Australian woody perennial plant species that may be considered as potential sources of feed for grazing ruminants. Anim. Feed Sci. Technol. 160:98-109.

Goel, G., H.P.S. Makkar, and K. Becker. 2008. Effect of Sesbania sesban and Carduus pycnocephalus leaves and Fenugreek (Trigonella foenum-graecum L) seeds and their extract on partitioning of 
nutrients from roughage and concentrate-based feeds to methane. Anim. Feed Sci. Technol. 147(1-3): 72-89.

Hristov, AN, C. Oh, J. Lee, R. Meinen, F. Montes, T. Ott, J. Firkins, A. Rotz, S. Dell, A. Adesogan, W. Yang, J. Tricarico, E. Kebreab, G. Waghorn, J. Dijkstra, and S. Osting. 2013. Mitigation of greenhouse gas emissions in livestock production - A review of technical options for non-CO2 emissions. FAO Animal Production and Health Paper No. 177 (Ed. P. J. Gerber, B. Henderson, and H. P. S. Makkar). FAO, Rome, Italy.

Jayanegara, A., E. Wina, C.R. Soliva, S. Marquardt, M. Kreuzer, and F. Leiber. 2011. Dependence of forage quality and methanogenic potential of tropical plants on their phenolic fractions as determined by principal component analysis. Anim. Feed Sci. Technol. 163:231-243.

Johnson, K.A., and D.E. Johnson. 1995. Methane emissions from cattle. J Anim Sci 73:2483-2492.

Kamalak, A., A.I. Atalay, C.O. Ozkan, E. Kaya, and A. Tatliyer. 2011. Determination of potential nutritive value of Trigonella kotschi fenzl hay harvested at three different maturity stages. Journal of Veterinary Faculty, Kafkas University. 17(4):635-640.

Kilic, U., M. Boga, M. Gorgulu, and Z. Sahan. 2011. The effects of different compounds in some essential oils on in vitro gas production. J. Anim. Feed Sci. 20:626-636.

Kim, E.T., C.H. Kim, K.S. Min, and S.S. Lee. 2012. Effects of plant extract on microbial population, methane emission and ruminal fermentation characteristics in in vitro. Asian-Australasian Journal of Animal Science 25(6):806-811.

Kouazounde, J.B., L. Jin, F.M. Assogba, M.A. Ayedoun, Y. Wang, K.A. Beauchemin, T.A. McAllister, and D.J. Gbenou. 2015. Effects of essential oils from medicinal plants acclimated to Benin on in vitro ruminal fermentation of Andropogon gayanus grass. J Sci Food Agric 95:1031-1038.

Kumar, R., and M. Singh. 1984. Tannins: their adverse role in ruminant nutrition. Journal of Agriculture and Food Chemistry 32:447-453.
Kumar, S.S., G. Navneet, M. Mehta, M. Mohini, P. Pandey, S. Shete, and K. Brisketu. 2012. Efficacy of garlic, eucalyptus and neem powders on rumen modulation, methanogenesis and gas production kinetics in wheat straw. Wayamba Journal of Animal Science 4:347-355.

Lopez, S., H.P.S. Makkar, and C.R. Soliva. 2010. Screening plants and plant products for methane inhibitors. In: Vercoe, P.E., Makkar, H.P.S., Schlink, A., editors. In vitro Screening of Plant Resources for Extra-nutritional Attributes in Ruminants: Nuclear and Related Methodologies. London, New York. p.191-231.

Makkar, H.P.S., M. Blummel, and K. Becker. 1995. Formation of complexes between polyvinyl pyrrolidones or polyethylene glycols and their implication in gas production and true digestibility in vitro techniques. British Journal of Nutrition 73:897-913.

Menke, K.H., L. Raab, A. Salewski, H. Steingass, D. Fritz, and W. Schneider. 1979. The estimation of the digestibility and metabolizable energy content of ruminant feedingstuffs from the gas production when they are incubated with rumen liquor in vitro. Journal of Agricultural Science (Camb) 93:217-222.

Menke, K.H., and H. Steingass. 1988. Estimation of the energetic feed value obtained from chemical analysis and in vitro gas production using rumen fluid. Animal Research Development 28:7-55.

Njidda, A.A., and A. Nasiru. 2010. In vitro gas production and dry matter digestibility of tannin containing forages of semi -arid region of north-eastern Nigeria. Pakistan Journal of Nutrition 9:60-66.

Okmen, G., O. Turkcan, O. Ceylan, and G. Gork. 2014. The antimicrobial activity of liquidambar orientalis mill against food pathogens and antioxidants capacity of leaf extracts. Afr J Tradit Complement Altern Med 11(5):28-32.

Ozturk, D., M. Kizilsimsek, A. Kamalak, O. Canbolat, and C.O. Ozkan. 2006. Effects of ensiling alfalfa with whole-crop maize on the chemical composition and nutritive value of silage mixtures. Asian-Australasian Journal of Animal Science 19(4):526-532. 
Purcell, P.J., M. O'Brien, T.M. Boland, and P.

O'Kiely. 2011. In vitro rumen methane output of perennial ryegrass samples prepared by freeze drying or thermal drying $\left(40{ }^{\circ} \mathrm{C}\right)$. Animal Feed Science Technology 166:175-182.

Schofield, P., D.M. Mbugua, and A.A. Pell. 2001. Analysis of condensed tannins: a review. Animal Feed Science Technology 91(1):21-40.

Thao, N.T., M. Wanapat, A. Cherdthong, and S. Kang. 2014. Effects of eucalyptus crude oils supplementation on rumen fermentation, microorganisms and nutrient digestibility in swamp buffaloes. Asian-Australasian Journal of Animal Science 27(1):46-54.

Thao, N.T., M. Wanapat, S. Kang, and A. Cherdthong. 2015. Effects of supplementation of eucalyptus (E. camaldulensis) leaf meal on feed intake and rumen fermentation efficiency in swamp buffaloes. Asian-Australasian Journal of Animal Science 28(7):951-957.
Van Soest, P.J., and R.H. Wine. 1967. The use of detergents in the analysis of fibrous feeds. IV. Determination of plant cell wall constituents. J Assoc Off Anal Chem 50:50-55.

Van Soest, P.J. 1963. The use of detergents in the analysis of fibrous feeds. II. A rapid method for the determination of fiber and lignin. J Assoc Off Anal Chem 46:829-835.

Yapici, H.H., T. Batgar, C. Metin, and Y. Alparslan. 2015. Determination of the effects of sweetgum extract obtained from incense tree (Liquidambar orientalis) on the shelf life and quality of cultured sea bass (Dicentrarchus labrax). Journal of Nutritional Health and Food Science 1(4):166-177.

Yogianto, A., E. Sudarman, and A. Jayanegara. 2014. Supplementation effects of tannin and saponin extracts to diets with different forage to concentrate ration on in vitro rumen fermentation and methanogenesis. J. Indonesian Trop. Anim.Agric. 39(3):144-151. 